\title{
A NEWLY DISCOVERED PHOTOGRAPH OF GEORGE WASHINGTON WHITMAN
}

In 2007, I purchased from a collector of old photographs a previously unrecorded photograph with a name scrawled on the back: "Col. George Whitman." This photograph, reproduced on the back cover of this issue, does in fact appear to be of Walt's brother George Washington Whitman, who retired from the army in 1865 as a lieutenant colonel by brevet: key features in this photo match those in the known photo of a much younger George as a soldier. ${ }^{1}$ A side-by-side comparison shows what appear to be the same chin dimple, nose, and left ear, for example.

The newly discovered photograph is pasted onto a stiff cardboard backing with the credit, at the bottom left and right corners, "P. E. Chillman 914 Arch St." ${ }^{2}$ Philip Edward Chillman was known in the 1880s as the best portrait photographer and portrait painter in Philadelphia. ${ }^{3}$ In conjunction with a group of assistants, he created pastel, crayon, india ink, and oil portraits of many of Philadelphia's leading citizens.

On February 11, 1878, when Walt Whitman and Harry Stafford were photographed at the studio of Augustus Morand (just down the block), the 914 Arch Street address was occupied by painter W. Howard Michener, and Whitman noted that the photo with Harry was "for Michener," as if he wanted to have it painted. ${ }^{4}$

The photo of George Whitman was probably taken in the mid-1880s. Perhaps George, who moved to Burlington, New Jersey, in 1884, had this photo taken as a remembrance for Walt when he returned to visit the PhiladelphiaCamden area between August 7 and September 24, 1885; during this time, he checked in on Walt, who had been suffering another spell of bad health. ${ }^{5}$ This photograph adds to the small store of known photographs of Whitman family members. Because it was taken at a location Walt himself was familiar with, an easy ferry ride from Camden, it seems likely that the poet himself may have prompted its creation.

University of Nebraska — Lincoln

Kenneth M. Price

\section{NOTES}

1 For a reproduction of the earlier photograph of George Whitman, see Robert Roper, Now the Drum of War: Walt Whitman and His Brothers in the Civil War (New York: Walker \& Company, 2008), 236; for George's rank, see Roper, 356n. An even earlier photo of George, taken soon after he enlisted, appears in Civil War Letters of George Washington Whitman, ed. Jerome Loving (Durham: Duke University Press, 1975), following p. xvi; and in Roper, 3.

2 For more specific biographical information on Chillman, see Who Was Who in American Art. 400 Years of Artists in America, ed. Peter Hastings Falk (Madison, CT: Sound View Press, 1999). 
3 See "Philadelphia's Leading Industries" in City of Philadelphia: Leading Merchants and Manufacturers (New York: Historical Publishing Company, 1886), 186. Thanks to Ed Folsom for pointing out this reference.

4 City of Philadelphia, 186, mentions that Chillman had been at 18 South Eighth St. and had moved in the recent past, so it seems probable that he succeeded Michener at the Arch Street location. See Walt Whitman, Daybooks and Notebooks, ed. William White (New York: New York University Press, 1978), 1:85; see also the notes on the Whitman-Stafford photo on the Walt Whitman Archive (www.whitmanarchive.org).

5 I am indebted to Ted Genoways for this suggestion. See Whitman, Daybooks and Notebooks, 2:365-369. 